\title{
Molecular characterization of population level genetic diversity of several endemic species of Thymus L. (Lamiaceae) by using ISSR markers
}

\author{
Emirsaliiev A.O.*, Brailko V.A., Mitrofanova I.V. \\ Federal State-Funded Institution of Science "The Labor Red Banner Order Nikita Botanical Gardens - National Scientific \\ Center of the Russian Academy of Sciences", Yalta, the Russian Federation \\ *e-mail: asantaraqtasli@gmail.com
}

Key words: Thymus pseudohumillimus, endemic flora, PCR, polymorphism

Motivation and Aim: A Thymus L. is one of the largest Lamiaceae genera with great practical value. Studies of perspective thyme species introduction is problematic due to the extra endemism coupled with wide infra-generic hybridization possibilities and numerous spontaneous hybrids known, high morphological polymorphism and unclear taxonomic status of a most species $[1,2,3]$. The goals of this work were preliminary study of population level genetic polymorphism of a narrow endemic species of Crimean Flora, belonging to the Western Yailae group - Thymus pseudohumillimus Klokov et Des.-Shost., and a forecast on it's population sustainability.

Methods and Algorithms: DNA was extracted from fresh young leaves of Th. pseudohumillimus (six individuals), agg. Th. roegnerii K. Koch (two individuals) and putative hybrid of theirs (two individuals) according to the $\mathrm{CTAB}$ protocol with addition of $2 \%$ polyvinylpyrrolidone. Quality and quantity of DNA extracted were analyzed on NanoPhotometer NP80 (Implen, Germany). For PCR, BioMaster HS-Taq PCR $(2 \times)$ commercial kit (Biolabmix, Russian Federation) was used. DNA was amplified with 35 cycles using $\mathrm{C} 1000^{\mathrm{TM}}$ Thermal Cycler (Bio-Rad, Singapore) in regime: initial denaturation at $94{ }^{\circ} \mathrm{C}$ for $2 \mathrm{~min}$, cyclic denaturation at $94^{\circ} \mathrm{C}$ for $30 \mathrm{sec}$, proceeding to the primer-specific annealing and elongation at $72^{\circ} \mathrm{C}$ for a 1 min each, and final elongation at $72^{\circ} \mathrm{C}$ for $7 \mathrm{~min}$. For UBC-824 and UBC-826 annealing temperature was $55^{\circ} \mathrm{C}$, and for UBC-864 and UBC- $880-52^{\circ} \mathrm{C}$.

Results: The amount of DNA, obtained from $100 \mathrm{mg}$ of fresh leaves, has been $28 \mu \mathrm{g}$ with ranging between 7 and $52 \mu \mathrm{g}$. Purity has been scored with $\mathrm{A}_{260 / 230}$ and $\mathrm{A}_{280 / 260}$ spectres, locating accordingly at 2.072 and $2.236 \mathrm{~nm}$.

The UBC-824 primer was more polymorphic. The bands number varied from 7 to 11 with size 200-2,000 bp. Gels after electrophoresis were analyzed and on binary matrix base, UPGMA and Neighbor Joining dendrograms performed [4]. Putative hybrid individuals ended with agg. Th. roegnerii into a single clade.

Conclusion: ISSR PCR analysis has showed that the Th. pseudohumillimus is highly polymorphic and has molecular similarities to the $T$. roegnerii.

Acknowledgements: Investigation was performed in the framework of the State Assignment № 0829-20190038 of the FSFIS "NBG-NSC" and done on the base of the Unique Scientific Installation "Scientific Center of Plant Biotechnology, Genomics and Conservation" of the FSFIS "NBG-NSC".

\section{References}

1. Tohidi B., Rahimmalek M., Trindade H. Review on essential oil, extracts composition, molecular and phytochemical properties of Thymus species in Iran. Industrial Crops Products. 2019;134(August):89-99. doi:10.1016/j.indcrop.2019.02.038.

2. Yousefi V., Najaphy A., Zebarjadi A., Safari H. Molecular characterization of thymus species using ISSR markers. Journal Animal Plant Sci. 2015;25(4):1087-1094.

3. Васюков B.M. О крымских тимьянах (Thymus L., Lamiaceae). Новости систематики высших растений. 2014;45:110-121.

4. Pavel, A.B., Vasile, C.I. PyElph - a software tool for gel images analysis and phylogenetics. BMC Bioinformatics. 2012;13(9). https://doi.org/10.1186/1471-2105-13-9. 